\title{
A NEW PARADIGM OF HUMAN EXISTENCE AS LEGAL IDENTITY IN THE ENTROPY SYSTEM
}

\author{
НОВА ПАРАДИГМА ЛЮДСЬКОГО БУТТЯ ЯК ПРАВОВОЇ \\ СУБ'ЄКТНОСТІ В СИСТЕМІ ЕНТРОПІЇ
}

\section{НОВАЯ ПАРАДИГМА ЧЕЛОВЕЧЕСКОГО БЫТИЯ КАК ПРАВОВОЙ СУБЪЕКТНОСТИ В СИСТЕМЕ ЭНТРОПИИ}

\author{
Lisovskiy P.
}

Dr. of Philos. Sc., Professor, Chair of Department of International Law, International Relations and Social Sciences and Humanities of Open International Human Development University “Ukraine”, Kyiv, Ukraine. E-mail: syngaipm@i.ua.

\section{Lisovska Yu.}

Ph.D. (Law), Associate Professor of the Department of Administrative, Financial and Banking Law, EducationalScientific Institute of Law of the Interregional Academy of Personnel Management, Kyiv, Ukraine. E-mail: ivsd@i.ua.

\section{Лісовський П. М.}

Доктор філософських наук, доцент, професор кафедри міжнародного права, міжнародних відносин та соціально-гуманітарних дисциплін Відкритого міжнародного університету розвитку Людини «Україна», Київ, Україна. E-mail: syngaipm@i.ua

Лісовська Ю. П.

Кандидат юридичних наук, доцент кафедри адміністративного, фінансового та банківського права, Навчальнонауковий інститут права Міжрегіональної Академії управління персоналом, Київ, Україна. E-mail: ivsd@i.ua

\section{Лисовский П. Н.}

Доктор философских наук, доцент, профессор кафедры международного права, международных отношений и социально-гуманитарных дисциплин Открытого международного университета развития Человека “Украина”, Киев, Украина. E-mail: syngaipm@i.ua

\section{Лисовская Ю. П.}

Кандидат юридических наук, доцент кафедры административного, финансового и банковского права, Учебнонаучный институт права Межрегиональной Академии управления персоналом, Киев, Украина. Е-mail: ivsd@i.ua.

Abstract. In the article, the authors substantiates the modern model of the interman as a creative cyber personality, which has the potential to be identified with the correspondence of virtual bodies as a problem of modern culture. It is emphasized that it is precisely this functional possibility that finds out a new paradigm of human existence, in which entropy as a criterial device modernizes modern society. It is determined that the most intelligently gifted people are able to master the noosphere space of being through the phenomenal wisdom recipes. This content shows entropy as a defining modus of probable processes, in which modernization of a modern person, state and society takes place, since the criterion of the entropy apparatus is the recognition of that random fact (events, situations) that becomes logical. It is emphasized that the main direction of risk processes in the phenomenal wisdom recipes for the personality, the state and society should be truly chosen in the entropy system, carefully studying the theory of probable functions. It is revealed that ideological borrowings contain a considerable danger, since ideology has a class modification due to the modernization of a certain class on the basis of samples of another's experience. It is concluded that this may lead to an urgent inter-class conflict, to strengthen, oppositional sentiment. An overview of modernization as an entropy of risk processes is given, which is the mainstream in a particular historical retrospective of phenomenal consciousness. It is emphasized that modernization means the creation of a new type of world order, in which human being plays an 
anthropocentric role at the level of legal subjectivity. The constructive and destructive Spirit of Time according to the entropy criteria is confirmed. Different forms of crisis are revealed when exhausting the established norms and rules of behavior of individuals, groups, classes, ethnic groups, communities. It is envisaged that science is such a fundamental innovation in which entropy depends to a large extent on the mental and value orientations of an individual people, based on consciousness, language, culture, etc. Creation of complex of measures and procedures is envisaged including the risks concerning maintenance of human life and health in the legal state.

Key words: paradigm, being, interman, modernization, legal subjectivity, crisis, legal entropy, information policy.

Анотація. У статті автори обтрунтовують сучасну модель інтермена як креативної кіберособистості, щзо має потенційну можсливіть ідентифікуватися з відповідними віртуальними тілами як проблематизація сучасної культури. Підкреслено, щцо саме така функиіональна можливість $і$ з'ясовує нову парадигму людського буття, в якій ентропія як критеріальний апарат модернізує сучасне суспільство. Визначено, щуо саме розумно обдаровані люди завдяки духовному капіталу мудрості здатні освоїти ноосферний простір буття. У цьому змісті показано ентропію як визначальний модус імовірних процесів, в якій відбувається модернізачія сучасної особи, держави та суспільства, оскільки в основі критеріального апарату ентропії є визнання того випадкового факту (подї, ситуації), щчо стає закономірним. Підкреслено, щуо має бути істинно обраний в системі ентропії магістральний напрямок ризикових процесів у феноменальних рецепщіях мудрості для особистості, держави та суспільства з огляду ретельного вивчення теорії імовірних функцій. Виявлено, щуо ідеологічні запозичення містять у собі значну небезпеку, оскільки ідеологія має класову модифікацію в силу осучаснення певного класу за зразками чужого досвіду. Зроблено висновок, щзо ие може спричинити неминучий міжкласовий конфлікт та посилити опозиційні настрої.

Дається огляд модернізащії як ентропійному засобу ризикових процесів, яка $\epsilon$ магістральним напрямком у конкретній історичній ретроспективі феноменальної свідомості. Підкреслено, щуо модернізаџія означає створення нового типу світового порядку, в якому людське буття на рівні правової суб'єктності відіграє антропоцентричну роль. Стверджено конструктивний та деструктивний Дух Часу відповідно до ентропійних критеріїв. Виявлено різні форми кризи, коли вичерпують себе усталені норми та правила поведінки окремих осіб, груп, класів, етносів, спільнот. Передбачено, щуо наука-це така фундаментальна інновачія, в якій ентропія значною мірою залежить від ментальноціннісних орієнтирів окремого народу, виходячи із свідомості, мови, правової культури тощзо.

Ключові слова: парадигма, буття, інтермен, модернізачія, правова суб’єктність, криза, правова ентропія, інформаційна політика.

Аннотация. В статье авторы обосновывают современную модель интермена как креативной киберличности, что имеет возможность идентифицироваться $c$ соответственныли виртуальными телами как проблематизащия современной культуры. Подчеркнуто, что именно такая функциональная возможность и выясняет новую парадигму человеческого бытия, в которой энтропия как критериальный аппарат модернизирует современное общество. Определено, что именно разумно одареннье люди благодаря духовному капиталу мудрости способны освочть ноосферное пространство бытия. В этом смысле показано энтропию как определяющий модус возможных процессов, в котором происходит модернизация современной личности, государства и общества, поскольку в основе критериального аппарата энтропии является признание того случайного факта (события, ситуации), что становится закономерным. Подчеркнуто, что должно быть истинно избрано в системе энтропии магистральное направление рисковых прочессов в феноменальных рецепциях мудрости для личности, государства и общества с учетом 
тщңательного изучения теории возможных функций. Выявлено, что идеологические заимствования включают в себя значительную опасность, поскольку идеология имеет классовую модификацию в силу осовременивания определенного класса по образиам чужого опыта. Сделан вывод, что это может привести к неизбежным межклассовым конфликтам и усилить оппозиционные настроения.

Дается обзор модернизачии как энтропийного средства рисковых прочессов, которая является магистральным направлением в конкретной исторической ретроспективе феноменального сознания. Подчеркнуто, что модернизачия означает создание нового типа мирового порядка, в котором человеческое бытие на уровне правовой субъектности играет антропоцентрическую роль. Утверждено конструктивный и деструктивный Дух Времени согласно энтропийных критериев. Выявлены различные формы кризиса, когда исчерпывают себя устоявшиеся нормы и правила поведения отдельных лии, групп, классов, этносов, сообществ. Предусмотрено, что наука - это такая фундаментальная инновация, в которой энтропия в значительной степени зависит от ментально-ценностных ориентиров отдельного народа, исходя из сознания, языка, правовой культуры и тому подобное.

Ключевые слова: парадигма, бытиё, интермен, модернизация, правовая субъектность, кризис, правовая энтропия, информаџионная политика.

Research rationale. In the modern information world, due to computer technologies, a person has the opportunity to experience a huge number of different feelings. It is a kind of "digital physicality" of irrational nature that has a purposeful extrasensory action as a way out to a new electronic environment of existence. In this context, cyber-personality as a creative interman has a potential opportunity to identify itself with any virtual bodies selected by it, which moves it away from its own living corporeality. Just this constitutes one of important problematizations of modern culture.

As a matter of fact, virtual space is designed for a "living body", which aims to provide the biological organism mainly with matter and energy, endangering the existence of the physical body of a person. In other words, potential social worlds generated by intermen do not remain aloof from the universal planetary life generated by them, but continue to cooperate actively with it. Therefore, modern mankind approaches the field form of human existence as a qualitative new totality discovered from without. It binds to an appropriate view of it from within as of something concrete, something, which "unfolds in itself and maintains unity, that is, totality" [Hegel, 1974: 100].

Thus, this conclusion is in compliance with the idea of K.E. Tsiolkovsky of the transition of humanity in the future to the phase of the existence of pure energy, which is called "radiant humanity". This corresponds to a certain extent with the ancient esoteric teachings which affirm that humanity, in the process of its evolution, undergoes phases of the gradual embodiment of pure spirit in matter (spirit as body, and body as spirit).

Taking into account it, self-determination of individual and state occurs in the entropic process of modern development of Ukraine when the system of legal market relations is only formed. Therefore the problem of investment activity becomes urgent in cryptooperationsystem of information capital that contains inter-branch character [Kovalchuk, 2017:47]. It is thus considered that investments as the component of clean spending embrace spending on the infrastructure, health protection, various service business and so forth. The mentioned problem is in the centre of debatable attention of scientists, as it is related to the entropic process of self-determination. Just the same process presents the theory of accidentally-natural functions where effectively numerical parameters operate in the nonlinear system of the informatively legal and financial legal field.Methods. The author used systematic, logical, axiological and other methods of research.

Formulation of the problem. With the current development of intelligence science and the ability to exert active influence on the world of "raw" matter, a new stage in the development of the spiritual capital of wisdom in modern times begins as a transition to the energy level of life. In this case, the organizational existence of the planetary community during the XXI century takes possession of qualitatively new space, namely, the noosphere. Therefore, there is a topical 
contradiction between the biological body of a person that makes the latter stay in the planetary space and cultivation by the human mind of new source meanings (semantic structure of consciousness). It is to this end that man appeared in the universe, which nourishes him with creation of meanings, and therefore just the meaning of the life of a person determines his behavior. According to V.V. Nalimov, "the meaning of our lives consists, first of all, in looking for the meaning” [Nalimov, 1989: 20].

In such a context, the most probable is that it is intellectually gifted people, as the manifestation of their phenomenal receptions of wisdom, who are capable of mastering the noosphere space of being. In this case, a fundamental factor that changes the world is the brewing of a new era, about which American thinker Charles Kupchan wrote: "Now, a new era - the digital era - has come. The industrial society is decaying increasingly apparently as the introduction of digital technologies takes place. The decline of the industrial era and the transition to a digital economy are capable of shaking the foundations of democratic statehood. This turbulence will accompany the return to a multipolar world and ensure growing tensions between the leaders and outsiders of the digital technological race" [Kapchen, 2004: 526].

In the case of assessing the future condition of man, scientists single out challenge man, network man or networker, pontiff man, navigator man, who, in the words of Russian researcher S. Smirnov, are also "men of transition" or homo ludens [Smirnov, 2006: 122]. It is the new image of man that is determined as post-man being a hybrid of man and machine, that is, a "cyborg”, which is disconnected from external stimulants of irritation.

In our opinion, interman is the person of the future, whose life is closely connected with social networks of the Internet, and who is a network co-author. Psychologically, interman is tied to processes in the Network as a "member of this family". Based on the nature of social activity, interman, if necessary, acquires creativity, which ensures his pioneering existence. Among such features, the activation of interman in a social network, his self-creation and self-design with the aim of the desired volitional self-image, which is maximally harmonized with the existing social reality, are worth noting.

As Ye. Gornyi finds, in the absence of corporeality in a virtual personality, we have to perceive it as something created exclusively from signs and actions. In this case, "it is not the nature of the carrier, but the effect produced in the psyche by the responsible complex of signs that is important” [Gornyy, 2004: 78].

Thus, there is every reason to put forward a hypothetical picture that intermen are an embodiment of the information community due to the activation of attribute properties. Such a newly formed community, an example of which is interman, can acquire during the 21st century the transition state from planetary to cosmic being, objectivizing voluntariness and legal independence in the civilization field.

Analysis of recent research and publications. Analysis of literary sources allows testifying that questions of the paradigm of human existence as legal identity, in which culture constructs the future, aroused interest in all periods of the development of personality, state, and society. In turn, human activity, in which culture is the spiritual core of wisdom, was considered in the age of Enlightenment by such thinkers as F. Bacon, T. Hobbes, J.-J. Rousseau. Another approach to the vision of culture as legal identity in human existence was proposed by I. Kant, who singled out the culture of skills and the culture of discipline in the system of science and art. According to the teaching of N. Machiavelli, there must be a law in the state that establishes stable and inviolable rules of legal policy. With the powerful development of science, technology, and man himself, the approaches to the necessary awareness of the essential characteristics of culture as a driving force of new progress, in which the new information person is the source, change, too. It is the system of information values that occupies a fundamental position in the structure of human consciousness. In this case, various interpretations of the unity of the historical and cultural process that were substantiated in writings of O. Spengler, W. Dilthey, G. Simmel, E. Husserl, M. Weber as well as in the field of the theory of mentality - in works of F. Braudel, A. Moles, E. Fromm, T. Parsons, C. Kupchan, R. Merton, and others, played an important role. Among contemporary Ukrainian 
researchers, it is necessary to mention: V. Andruschenko, V. Bekh, V. Voronkova, L. Huberskyi, I. Nadolnyi, M. Kurko, M. Popovych, M. Nedyukha, M. Ozhevan, and others. It is their scientific research that reveals a new paradigm of man in the context of information values of ideologies, language, and legal culture.

Besides, such modern home researchers as O. Baranivsky, E. Boichenko, I. Hrytsenko, L. Lazbenyk, A. Peresada, T, Cheknina, E. Ostrovska and others touch upon the problem of investment activity in the informatively-legal field of entropy. Therefore the mentioned range of problems is complicated and little-investigated, and causes debatable interest. At the organisationtheoretical basis of investing it is necessary to use a legislative base, in particular the Law of Ukraine "On investment activity". Singling out previously unexamined parts of the overall problem. The significance of the new paradigm of human existence as legal identity just in the modern information culture has a discursive nature, since it is interpreted not only in terms of meaning but also in ways and methods of social communication. Such information interaction is connected with the process of production of information, the basis of which is represented by systems of values that contribute to the formation of ideology in the structure of human consciousness [Lisovska, 2017:26]. At the heart of informational axiology there is motivation of human activity, which expresses the self-awareness of an individual or any social group. In this case, the methodological foundations of the study of the new paradigm of human existence are represented by the interdisciplinary approach that is based on such sciences as cosmobiology, cosmopsychology, virtuality science, transhumanism, eco-ethics, personal psychology as sciences about reflection and technology of transformation of man and universe, as well as by methods and means that are used for analysis - the informological one, the axiological one, the entropy one, etc.

Setting the objective. The objective of the article is: to consider and substantiate the new Man of the XXI century as legal identity in the socio-cultural field of activity; to reveal the noosphere space of human existence; to show entropy as a fundamental modus of probable processes; to define modernization as an entropy means of risk processes; to predict for the future entropy criteria in the phenomenal matrix of human existence.

Presenting the main material. It is advisable to take as a basis for theoretical and practical conceptualization of human existence entropy as the defining mode (tool, attribute, technology, etc.) in the system of randomly-regular functions. It is such a functional possibility that establishes the new paradigm of human being, in which entropy as the criterial apparatus modernizes modern society [Lisovskyi, Lisovska, 2017: 181].

Therefore, it became clear that modernization means creating a new type of world order, in which human existence plays an anthropocentric role. It is particularly intensively developed within the framework of UNESCO research centers and consists of three main autonomous and interconnected components: a new economic order, a new political order, and a new cultural order [Banga, 2013:18].

At the heart of these entropy approaches there is the recognition of the random fact (event, situation) that becomes logical as the modernization of the world community, and not of a single country or region.

Because borrowing, assimilation, and imitation are practices of entropy examples. In this case, imitation is necessary for two reasons: a) due to the objective impossibility to fluctuate (single out) certain phases of historical development; b) in order to save resources. It is assumed that borrowing already existing examples, taking into account mistakes and others' negative experiences, allows the recipient to avoid different turns, to operate more efficiently, economically, and systematically.

However, modernization is rather a contradictory probable process. In this way, first of all, there are purely objective obstacles, including those of systemic nature. This, in particular, was noticed by American researcher R. Merton, who put forward a thesis about fundamental limitation of system borrowing, of mutual or unidirectional transformation of systems. Its essence lies in that random elements of one system cannot be transferred to another system without their prior significant transformation, since the system itself has a hierarchical structure [Lisovskyi, Podolyaka, 
Lisovska, 2019: 85]. Previously, the transformation should be carried out by a reformer or innovator, who forces a new element that got accidentally (mysteriously) in its environment, to act according to its own, specific only to it, rules and laws. If this happens, then the recipient system enters a range of internal tension, social arrhythmia, and therefore it makes mistakes, experiencing structural and functional losses.

According to the laws of the nature of human existence in the universe (in the coordinates of human-centeredness and human-cosmicity), there must be a correspondence between the proper levels of power of the borrowing system and the borrowed (sample) element [Lisovskyi, 2017: 59]. The discrepancy of the levels leads to dysfunction of the system of adaptive and socio-creative possibilities.

For example, the western model of education, which is effective in itself, if transferred to a tribal environment, in which traditionally oriented persons with magic-mythological perception of reality inherent in them operate, will function ineffectively. Because it does not correspond to the mental nature of this social environment, since it can only be transformed according to local conditions (thus, scientific and technical knowledge, other forms of rationalization of thinking and actions acquire a magic-mythological interpretation, and practical actions based on them fit into the structure of the traditional human lifestyle) [Lisovskyi, 2019: 155].

In the case when borrowed elements appear stronger than their new environment, they can undermine traditional functions of the system, but do not guarantee its overall effectiveness. In order for this to happen, Time in Time as a naturally determined event (opportunity) of Life is needed.

In addition, the number of borrowed new elements should not exceed the number that the system can assimilate. Otherwise, there is a new dependence: the power of borrowed elements prevails over the adaptive capabilities of the recipient system. The former undermine the basis of the existence of the system; deprive it of the internal order and integrity, autonomy and tradition of the existence. Therefore, the very formation of new man, morals, law, collective psychology, ideology, mental-value orientations, regulatory mechanisms, etc. will be accompanied by the loss of what will already have been acquired.

In other words, the dramatic nature of the situation is just in the fact that in today's information society just those random elements to create which modernization is introduced are absent.

\section{Modernization as an entropy means of risk process}

It is common knowledge that modernization, especially at the initial stage, does not provide for significant amounts of the accumulation of social wealth, since it is the accumulation of modes of action - scientific knowledge and technology. Only having reached a new level of maturity, such fundamental modes can ensure accumulation on such a scale that the society in question transits to spiritual production - its own science, culture, and education.

In such a context, it is economic modernization as an important instrumental matrix of the mode definition of entropy that largely occurs due to equipment of labor force based on the import of technology. After all, the reorganization of the social and technical organization of labor involves a certain reform of property relations, approval of new management technologies with obligatory consideration of risk processes based on the theory of random functions. Hence, a significant transformation of existing industrial organizations as a new paradigm of human existence is created.

In general terms, it can be argued that, at the time of modernization, the division of labor between the subjects of ownership should be consistent with the effective economic activity. After all, it is possible to carry out painless and accelerated accumulation if in the entropy there are hardto-get natural resources and a responsible, organized, and disciplined political elite. This is exactly the case of the Arab Emirates and other Middle Eastern countries, which, on the basis of oil exports, turned the desert into a blossoming garden.

If, on the other hand, the political strategy of the elite is not truly correct, but only irresponsible, corrupt, and uncontrollable, then sooner or later such a strategy can be defeated, that is, it leads to self-destruction as the implementation of utopia at the international level. Therefore, 
the main direction of risk processes in the phenomenal receptions of wisdom for the individual, the state, and society should be truly chosen based on careful studying the theory of probable functions [Lisovskyi, Lisovska, 2019: 27].

In this sense, ideological borrowings are a considerable danger, since ideology has a class modification due to the modernization of a certain class on the basis of examples of outside experience. This can lead to an acute inter-class conflict, to strengthen oppositional sentiments.

Therefore, in the state, a law must be in force which would establish solid and inviolable rules for all, equal opportunities, and clear limits for the permissible that nobody has the right to step over. At the same time, the rules of politics, according to N. Machiavelli, are rigid, cynical, immoral, and unprincipled. But it is with the help of such political technologies that one can get, and, most importantly, hold power, carry out reforms and transformations in the state system.

Thinker N. Machiavelli comes to the conclusion that change of ruling elites is a regularity of politics, since it is based on objective needs of social groups as well as on the psychology of man. The researcher believes that, for the safety of a new state, it is best to destroy all the memories of the old ones [Machiavelli, 1982: 143]. According to the teachings of Machiavelli, it is the nobility that is the main cause of the collapse of states and the destruction of all morality and civic virtues [Machiavelli, 1982: 227].

Consequently, borrowing an outside religious or secular utopia can lead to a significant sign and symbolic transformation of the consciousness of the individual or nation in question. In order for this to happen, it is necessary to study entropy as a criterial apparatus in the theory of random functions, which is important for the self-determination and identification of each individual, state, and society. It is advisable to achieve such a preservation of the originality (identity) by reorganizing the elements of one's own cultural capital on the basis of its harmonious combination with the context of wise borrowing from other countries of the world. In this context, the possibilities of the development of a particular society in a particular historical retrospective are determined by a phenomenal nature of consciousness as a property of human existence.

\section{Legal entropy as important criterion of investment activity of Ukraine}

Under the Law it is worth to refer such totality of values to the property and intellectual necessities that circulate through the market as: "monetary funds, specific banknote deposits, shares and other securities; chattels and real assets (buildings, constructions, equipment) and other tangible assets; property rights, that follow from a copyright, experience and other intellectual values (The law of Ukraine "On investment activity"). In fact our country is at a level, when main legal control is spared to the material assets - real estate, equipment, land and etc. Thus clear and faithful determination of rights on its possession and use must be preceded registration of object. Legal entropy (indefiniteness) of this question results in a situation when a product that got a patent in Government service of intellectual property of Ministry of Science and Education of Ukraine is being used or sold to quite another organization. However organization as an owner of product under the law cannot own information about the illegal use of the created product. It is possible both at the terms of conspiracy of extraneous organization with one of authors and without direct participation of author. Thus, totality of the mentioned values is accepted to refer to the objects of investment activity in which an intellectual investment must be lawfully valuable as a contribution to beneficent potential of society. All of it follows from the copyright, and the right of industrial ownership. Such an investor as a subject of legal entropy makes decision about investing of the personal, borrowed and attracted property and intellectual values in the objects of investing.

\section{Legal powers of investor in the modern terms of market}

As the Law provides, an investor can come forward as depositors, customers, creditors, and execute the legal functions of any participant of investment activity, that is invest, buy securities, and also perform the duties of customers. If an investor is a person who invests the personal and borrowed assets, then in relation to a creditor such person is partly a debtor [Lisovskyi, Lisovska, 2019: 27]. In turn, the legal subjects of investment activity implement their purposes, directions, 
kinds and volumes of investments in the entropic process of legal mutual relations, when investment climate as one of nonlinear parameters of entropy plays a considerable role in modern market conditions. Exactly these markets regulate the process of exchange investments and investment objects (merchandise). The forms of capital exports are direct capital investments, portfolio investments, and also loans and credits, functioning industrial, bank, trade and other capital of foreign countries that provide an investor of control over enterprise. Direct investments are the most typical for activity of transnational corporations (TNC) [9]. Besides, it is necessary to indicate that portfolio investments contain capital investment in bonds and shares of foreign companies, which are insufficient to establish direct performance monitoring. The main purpose of portfolio capital investments is profit earning, but not providing of direct economic performance monitoring of investing object. Thus, direct and portfolio investments are the varieties of enterprising capital that is meant for an investment in a production and aimed at the creation of new enterprises or on the purchase of part or absorption of already existent companies. Branches, subsidiary companies or mixed enterprises appear as a result of enterprise capital export [Holovatyi, 2014: 16]. During the use of foreign sources of raw materials on the base of direct investments the differences of ecological norms and standards of different countries are taken into account [4]. The developed countries try to carry such production capacities that result in considerable pollution of environment to less developed countries. Capital investment is an active motivation instrument of demand on domestic products. It is achieved due to, firstly, new markets are created abroad, and secondly, part of export of TNC is constantly used in foreign branches. Their part for today comes to over 1/3 the exports of Canada, Germany, France, Sweden, to 1/2 the export of the USA. For the purpose of legal introduction of the entropic process in the system of investment it is envisaged to: make changes and addenda to the foreign investment legislation; - maximally simplify procedures for regulation of legal mutual relations in sphere of attraction of foreign investments; - create a legislative base on issues of the relations settlement regarding foreign investments attraction in development of minerals and geodesic monitoring on the oil and gas deposits, and also define the proprietorship of investees. Such realization will facilitate the investment climate growth in Ukraine, creates preconditions for the appearance of permanent investment motivations at international partners [6]. It is necessary to agree that a "modern administrative law must be examined mainly as a means of ensuring of the proper abidance and effective protection of citizen rights and freedoms in the field of the state functioning". If the administrative methods of government control of economy are based on the state authority and involve prohibitions, permissions and duress, then they must be used for violations prevention including the sphere of investing. On the stage of legal reform the question is about the qualitatively new system of regulation of relations. Such mechanism can be effective, as it operates not arbitrarily, but on the basis of the scientifically weighted facilities of investment activity, in particular at responsibility application. It is worth to consider administrative and criminal responsibility as such effective facilities. It should be emphasized that the definition of the concept of responsibility is still actual. Some of the scientists consider administrative responsibility as a reaction on offence, in fact without offence there is no responsibility. Thus, to better the investment climate in Ukraine it is necessary:to improve a legal sphere and provide stability of investment legislation; - to extend an informative sphere for investment activity and projects worked out as per international standards. The legal grounds of information protection are stated by the legislation of Ukraine that envisages the legal regulation of information circulation in the society and defines the access mode to information.

Depending on the type of information there are appropriate rules of behaviour during realization of investment activity. According to the article 28 of the Law of Ukraine "On information", they are defined as the access mode, that envisages legal norms, an order of information getting, using, dissemination and storage [Lisovskyi, Lisovska, 2016: 127]. The legal mode content is defined by norms that set: an order of access to information, its use and protect; administrative and legal responsibility. Information that contains entrepreneurial interests under the Law "On information" by the access mode is divided on open information and restricted access information. According to the law a task of control on the access mode to information consists in 
providing of keeping of legislation requirements after the sphere of investment activity, nonadmission of the groundless information attribution to the category of information with restricted access. Confidential information belongs to restricted access information. The article 30 of the Law defines confidential information as information that is in possession, use or distribution by certain natural persons and legal entities and spreads at their desire subject to conditions established by these persons. Access mode to commercial information, including its belonging to confidential information, is defined independently by the owner of information. Commercial secret is one of the types of confidential information. Attributing of information to the commercial secret does not touch secret information that is a state secret circulation of which is governed by the Law of Ukraine "On a state secret". Attributing of information to the commercial secret is defined by the economic entity and specifies on a right of the owner on information that is guarded by legislation and contains a commercial value. Question of human rights and freedoms providing in networks of the Internet is resolved by the Decree of the President of Ukraine "On events concerning development of national constituent of global informative network the Internet and providing of wide access to this network in Ukraine" of July, 31, 2000.The law of Ukraine "On electronic documents and electronic circulation" lays down the unified requirements to the essential elements of electronic document that has legal force. This law defines electronic circulation of documents as "totality of the processes related to making, processing, sending, transfer, receipt, storage, use and elimination of electronic documents, which are performed applying integrity verification and, if required, with confirmation of fact of receipt of such documents." An electronic signature is an important essential element of electronic document, which is set for its authentication. The order of its use is regulated by the Law "On an electronic digital signature".

\section{Conception of safety in the banking system}

There are some regulatory and legal acts that govern the principles of information protection in investment activity that is inherent for the banking system. Thus, the legal mode of information protection in automated systems is separately defined as over 65 percents of bank information circulate in automated systems.According to the legislation, access to information that is kept, processed and transferred in automated systems, is implemented as per rules of access delimitations, that is set by an information owner or a person authorized by him (article 6 of the law of Ukraine "On protection of information in automated systems "), as in this case a right for protection of information is entrusted to its owner - bank [3]. Activity of the Ukrainian banks concerning providing of their safety is governed by not only a current legislation but also internal normative acts. Banks develop Provision for safety department and other documents concerning safety measures realization in accordance with conception of bank safety. To secure normatively, an order that approves Provision for information of bank with a restricted access is issued. Provision envisages the information list that is commercial secret and confidential information of bank, composition, persons, whom this information can be conveyed in full, measures of information protection that is a commercial secret, banking secrecy and confidential information. The analysis of safety results of banks activity shows that not all banks fully create a normative base and use it effectively. Small experience on these questions is only in particular banks. Such banks have normative documents (orders, instructions, provisions, recommendations) for realization of informative audit and informative monitoring in their organizations. The informative monitoring envisages information receipt control to define its importance, value and possibility of the use in the integrated databases of safety departments [Sinha, 2009: 40]. Permanent realization of such work in banks gives possibility to create an informative base of investment activity, and combination of this work with other measures of the information and analytical providing gives an opportunity to create a necessary informative resource.

\section{Collaboration of Ukraine with the countries of the Islamic world in investment sphere}

Among the complex of measures to form investment principles, it is necessary to distinguish the following. For realization of existent possibilities of providing qualitatively new level of collaboration of Ukraine with the Muslim countries of Near and Middle East and South-East Asia in 
an investment sphere it is expedient to involve Consultative board concerning the foreign investing of representatives of financial and business circles of above mentioned territories. It is necessary to create the system of guarantees from the side of the Ukrainian state for the Near-Eastern and SouthEast-Asian partners, by effecting bilateral agreements with the interested partners to protect investments. And also to work out legislative safety guarantees of investment collaboration of Ukraine with an Islamic bank capital. At the same time, it is necessary to conclude an appropriate agreements with the Islamic bank of development and form with it and other leading financial structures of Near and Middle East, Persian bay, South-East Asia (Fund of investments of Kuwait etc.) a package of attractive investment projects in major industries of economy, development of science and nanotechnologies, tourist country-specific studies, education and art. Organization in Ukraine of business forums for businessmen and financiers from Muslim countries with an active participation of leading financial structures of the Islamic world is an inalienable constituent of the mentioned work direction. The special attention must be concentrated on setting up of a system of proper consulting services by creation of information and analytical centres that would be able to render necessary services in setting up contacts of Ukrainian business and entrepreneurship with the financial structures of the Islamic world, to provide necessary legal accompaniment of businessprojects preparation, conclude agreements and other services. Preparation of necessary training aids on activity of Islamic banks and a dictionary of Islamic terms is acquired an important significance. It is important to translate into the Ukrainian language of the proper scientifically-methodical literature of the mentioned problem, especially when an experience of collaboration of Europe and North America countries with an Islamic bank capital is summarized. Foremost, it relates the sphere of the administrative and legal regulation and realization of collaboration organizational measures.

\section{Predictions of the future in accordance with entropic criteria}

In accordance with entropic criteria phenomenal forms and types of risks are possible in the system of accidental and logical functions, especially for the economic entity as constructive and destructive Time Spirit [Rouzet, 2014: 28]. The different forms of crisis appear thus, namely: the simplest is incongruity between the system and its particular accidental and logical elements and the most complicated are antagonism, severance of connection with greater part or even all elements.

Severance on axis "valued orientations - resources" gives rationality to crisis, the opposed directed divergence of aims and facilities of their achievement [De Backer, 2012: 8]. The extreme points of this crisis display can be excessive, expressive verbalism, empty political and ideological rhetoric or narrow pragmatism, vulgar productivism and virtual activism. Severance of public connection "man is a spiritual capital - society" lead to integration crisis, as the excessive cultural symbolism torn off from the real social structures prevails, when entrenched norms and behaviour rules of individuals, groups, classes, ethnos, community are exhausted.

Conclusions. For the future nature of the spiritual capital of wisdom, which tends in the modern information society to production, appropriate conditions should be created in order to further produce not only nanotechnologies, but also nootechnologies. To do this, a noosphere consciousness should be formed in the coordinates of human-centeredness and human-cosmicity. In this case, science should be used as a source of fundamental innovations, in which entropy occupies a decisive place, which to a certain extent depends on the mental and value orientations of an individual nation that has to choose its future based on consciousness, language, culture, etc.

Thus Ukraine in XXI century has actually unlimited reserves of some types of natural resources, extracting of which is the most attractive for foreign companies. Therefore a foreign capital is able to bring not only new equipment and technologies but also working assets, experience of marketing and modern management. For this purpose it is necessary to: make changes and addenda to the foreign investment legislation; maximally simplify procedures that govern legal mutual relations in foreign investments attraction sphere; extend an informative sphere for investment activity; systematize and regularly update the data bank of these investment projects according to the administrative and legal regulation and develop them under international approaches.

\section{References}


1. $\quad$ Banga R. (2013). 'Measuring Value in Global Value Chains' UNCTAD Working Papers 8: 34.

2. De Backer K. (2012). 'Mapping Global Value Chains' Causes and Consequences of Globalization: Final WIOD Conference', <http://www.wiod.org/conferences/groningen/Paper_DeBacker_Miroudot.pdf >

3. Djankov S. 'Private Credit in 129 Countries'. - Journal of Financial Economics, <http://www.doingbusiness.org/ /media/WBG/DoingBusiness/Documents/Methodology/Sup porting-Papers/DB-Methodology-Private-Credit-in-129-Counties.pdf?la=en>

4. 'Doing Business 2018' Getting Credit - Legal Rights Questionnaire «Survey_Economy_FullName», <http://www.doingbusiness.org/ /media/WBG/ DoingBusiness/Documents/Methodology/Survey-Instruments/DB18/DB18-Legal-RightsCreation-questionnaire-en.pdf?la=en>

5. Gereffi G. (2011). Fernandez-Stark K. 'Global Value Chain Analysis: A Primer' Durham: Center on Globalization, Governance \& Competitiveness, Duke University. 44 p.

6. 'Getting Credit Methodology'. (2017). Doing Business, $<$ http://www.doingbusiness.org/Methodology/Getting-Credit>

7. Holovatyi M. (2014). 'Multiculturalism as a means of nations and countries interethnic unity achieving'. Economic Annals-XXI, 11-12: 15-18.

8. Rouzet D. (2014). 'Services Trade Restrictiveness Index (STRI)', Financial Services, $<$ https://doi.org/10.1787/18166873>

9. 'Services Trade Restrictions Database'. (2018). The World Bank, $<$ http://data.worldbank.org/data-catalog/services-trade-restrictions>

10. Sinha B. (2009). 'Does Entry of Global Financial Services Brands Influence Commercial Borrowers in a Lesser Developed Economy?', ICFAI Journal Of Brand Management 6(2): 37-44.

11. Гегель Г. (1974). Эничиклопедия философских наук [Encyclopedia of Philosophical Sciences]. Москва : Мысль.

12. Горный Е. (2004). Онтология виртуальной личности. Бытие и язык [Ontology of the virtual personality. Being and language]. <http://www.zhurnal.ru/staff/gomy/texts/ovr.html>

13. Капхен Ч. (2004). Закат Америки : Уже скоро [Sunset of America: Soon]. Москва: ООО «Изд-во АСТ».

14. Ковальчук A. Ю. (2017). ‘Сучасна парадигма фінансово-економічної безпеки’ Jurnalul juridic national: teorie si practica, 3(25): 45-48.

15. Лісовська Ю.П. (2017). 'Вища освіта України як протидія корупційним маніпуляціям у законодавчому полі світової та європейської інтеграції’ Наукові праці МАУП 3 (54): 2431.

16. Лісовський П.М., Лісовська Ю.П. (2019). 'Парадигма міжвідомчого партнерства у сучасному квантовому світі: міжнародний сектор безпеки’ Актуальні проблеми міжнародних відносин: Збірник наукових пращь 138: 25-34.

17. Лісовський П. М. Лісовська, Ю.П. (2017). Інтелектуалознавство [Intellectuals]. К. : Кондор-Видавництво.

18. Лісовський П. М. (2017). Інформологія : Людина і Всесвіт [Informology: Man and the Universe]. К : Кондор-Видавництво.

19. Лісовський П. М., Подоляка С. А., Лісовська Ю. П. (2019). Спецслужби держав світу: ентропія, балістика, логістика : навчальний посібник [Special services of the states of the world: entropy, ballistics, logistics: a textbook]. К. : Видавничий дім «Кондор».

20. Лісовський П. М. (2019). Контррозвідка: квантова безпека та громадськість: навчальний посібник [Counterintelligence: Quantum Security and the Public: a textbook]. K. : Видавничий дім «Кондор».

21. Макиавелли Н. (1982) Избранньле сочинения [Selected works]. Москва : Худож. лит. 
22. Налимов В. (1989). Спонтанность сознания: Вероятностная теория смыслов $и$ смысловая архитектоника личности [Spontaneity of consciousness: Probabilistic theory of meanings and semantic architectonics of personality]. Москва : Прометей.

23. Смирнов C. (2006). Модели человека в современной философии и психологии [Models of man in modern philosophy and psychology]. Нижний Новгород: НОО «Профессиональная наука». 